\title{
Aspects of political theology in the spiritual autobiography of Dag Hammarskjöld
}

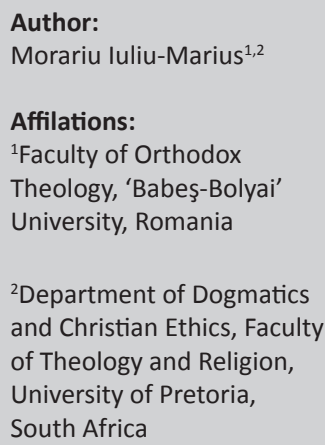

An important personality of the Swedish cultural space and of the world diplomatic space, Dag Hammarskjöld (1905-1961), left to posterity, besides his literary works, his economic and diplomatic contributions, the most important spiritual autobiography from the Swedish protestant space of the 20th century. Discovered shortly after his death and published by his disciples in 1963 in an English version in London (at Faber and Faber Publishing House), Markings presents the struggle of the author with himself, illustrated in a great diversity of styles, from haiku poems to short meditations, pastels (lyrics or prose), biblical exegeses and so on. Apart from the description of his spiritual life, his relationship with God, or his conception of spiritual issues, the work also contains some interesting references to aspects of political theology. These aspects represent the subject of our research. After a short presentation of his life and activity and of the influence of his family on his education, we will try to present the way in which aspects of political theology are emphasised in the aforementioned work and which are some important elements of the author's conception of this subject. In this respect, we will resort not only to his spiritual autobiography, but also to the most important writings about him, published by specialists in diplomacy, literature and politics. Unfortunately, it is difficult to find theologians who wrote about his spiritual autobiography (except some who talk about him in theological dictionaries). Therefore, one of the main strengths of this research will be the fact that it presents a theological approach to Dag Hammarskjöld.

\section{Introduction}

Despite its importance for contemporary theology, spiritual autobiography has not been analysed enough and highlighted until now. In works signed by researchers like Adam Smyth (2010, 2016), or in some theological dictionaries (like, e.g. Dinzelbacher 1992:82; Olver 1992:56), some of its important aspects are pointed out, but the subject is far from being known even a little in this space. Consequently, through our works, we have tried to bring to the attention of people this topic of research and to emphasise its contemporary elements (in books, studies and articles such as Morariu 2015:166-174; 2016:35-39; 2016a; 2016b:27-29; 2017b:113-123; Morariu \& Josan 2016:83-88). The aim of this article is the same: to offer to the reader an approach to an unknown component of spiritual autobiography.

Before doing this, it is also important to explain what spiritual autobiography is. Because of lack of space, we cannot afford a bigger approach and instead we shall try to simply point out several of its main aspects (for a more detailed approach, see Morariu 2017a:550-551). Part of the autobiographical genre, spiritual autobiography consists of diaries, memories or even autobiographical notes written by authors from different confessional backgrounds. The difference between spiritual autobiography and other autobiographical works is the fact that while the authors of other autobiographical works insist on the presentation of their own life, the authors of spiritual autobiographies focus on the presentation of their own mystical experiences, on the interaction with divinity and on the way this changes their lives.

Historically, it is almost generally accepted that spiritual autobiography starts with Saint Augustine's Confessions (Dinzelbacher 1992:82) and develops differently in various Christian spaces. Therefore, in the Catholic one, starting with Saint Teresa of Avila, there is a real revival of the genre and very interesting works have been published ever since. In the Protestant one, starting from the 18th century, many spiritual autobiographies have also been printed and many pastors have encouraged the publication of texts dedicated to the moment of evangelisation for proselytic purposes. In the Orthodox space, until now, there are only two books that can be considered to belong entirely to this genre, namely the autobiographies of Saint Silouane from Athos and of Saint John of Kronstadt. 
However, if the big topic we have mentioned must be discovered, why should anyone try to investigate one of its peripheral features? The answer is simple: because we wish to get deeper into the matter and to fully develop it, showing its complexity.

Therefore, we will try to present the main aspects of political theology that can be found in the spiritual autobiography of Dag Hammarskjöld (1905-1961), the second SecretaryGeneral of the United Nations (UN) between 1954 and 1961. It is very important for the spiritual autobiography of the Evangelic space from Sweden that not only his spiritual notes are special because of the alternation of writing styles (from haiku to pastels, meditations, long descriptions or imaginary dialogues), but also because of the diversity of the topics discussed.

\section{Dag Hammarskjöld and his spiritual autobiography}

Before talking about the proposed topic, we consider it important to present in a few words the life and work of the Swedish diplomat we are studying (Morariu 2016a:47-65). The son of Hjalmar Hammarskjöld (Globerman 1962:769), former prime minister of Sweden and custodian of the Nobel foundation of Agnes Hammarskjöld (Lash 1961:24; Lyonn 2006-7:81), a practicing Christian and nephew of Almquist, an important writer of the Nordic area during the Romantic period, ${ }^{1}$ he was born in Jonkoping on the 29th of July 1905. After graduating his studies in law, economy, the history of arts and philosophy at the universities of Uppsala and Stockholm (Hanley \& Melber 2011:9; Olver 1962b:131), he received a PhD in economy in Amsterdam, on the 4th of November 1933, with the dissertation entitled 'The Spread of Boom and Depression' (Erling 2010:7; Renton 2012:21), and one in Stockholm, where he would also become a professor of political economy (Hanley \& Melber 2011:9). There, he would also start his diplomatic career. In 1935, he became secretary of the National Bank of Sweden (Hanley \& Melber 2011:9) and, 1 year later, he became a Permanent Under-Secretary in the Ministry of Finance. Five years later, he would come back to the former institution, becoming its governor from 1941 to 1948 (Erling 2010:7; Olver 1962b:131). In this period, starting from 1945, he was also the financial counsellor of the Swedish Government and in 1947, he became Under-Secretary of the Ministry of Internal Affairs, being responsible for economic aspects. Between 1937 and 1948 he was also a member of the Scientific Committee of the Institute for Economic Research, which was under the coordination of the Swedish government. Moreover, in 1948, he participated in the Paris Conference as a delegate of Sweden, where the details of the implementation of the Marshall plan were established. In the same year, he was the leader of the Swedish delegation at the Conference of the Organization for European Economic Co-operation (OEEC), where he became for a while the President of this committee (Hanley \& Melber 2011:9).

1.For more information about his life and activity, see Olver (1962a:674) and Viklund (2008:1-23).
As a diplomat, he became the Under-Secretary-General of the Ministry of Foreign Affairs of his country in 1950, and, 1 year later, he was appointed a minister without portfolio (Hanley \& Melber 2011:9). Between 1951 and 1952, he participated, again in Paris, in the sixth session of the General Assembly of the United Nations as the vice-president of the Swedish delegation, and between 1953 and 1954 he was the president of the seventh session of the General Assembly of the United Nations (Hanley \& Melber 2011:10). This explains why, on 07 April 1954, he became the Secretary-General of the aforementioned institution (Globerman 1962:769; Mourre 1978:2143; Olver 1962b:131) and would be re-elected 3 years later (Globerman 1962:769; Mourre 1978:2143; Olver 1962b:131). From this position, he contributed to ending the crises of Suez, ${ }^{2}$ Algeria (Grosser 1965; Jacques 1998:110-111), Lebanon (Nantet 1986:330) and Congo, ${ }^{3}$ proving his qualities of negotiator and diplomat.

When he was elected, the former secretary warned him that he would then step into 'the most difficult job on earth' (Sabalbal 2013:3; Torren 2011:5: Uruquhart 1972:54). His tensioned relationships with leaders like Nikita Sergeyevich Chruschtschov (Uruquhart 1972:89) showed that this affirmation was almost correct. Nonetheless, by using his charm and his abilities in international diplomacy, he was able to increase the role of the Secretary-General of the United Nations and to solve many international problems that could have influenced the history of the world. Among his great successes in this area, we can mention his contribution to the release of the 15 American pilots who fought in Korea and were imprisoned in China. ${ }^{4}$ By refusing to obey the American orders and following the UN Charter (Uruquhart 1972:55), he managed to convince, during a visit of 2 weeks, the Korean communist government to accept the pilots' return home in the middle of the 1950s.

In parallel with his diplomatic activity, Dag Hammarskjöld was also an important and dynamic writer and promoter of culture. Not only his correspondence with Saint-John Perse (1993) and his support for the publication of the Long Day's Journey into Night of Eugene O'Neill (Uruquhart 2011:16-17), but also his writings, Castle Hill (Hammarskjöld 2000) and Waymarks (Aulen 1969; Erling 2010; Hammarskjöld 1972), made him one of the most important Swedish writers of his times. His qualities were recognised and rewarded through his election on 20th December 1954 as a member of the Swedish Academy like his father (Hanley \& Melber 2011:10). After his death, caused by the air crush from Ndola, he also received the Nobel Peace Prize, becoming one of the three people in history

2.For more information about this subject, see also Bromberger and Bromberger (1957), Burchell and Chassigneux (1967), Văduva and Dinu (2005), Siegfried (1948) and Roger and Roger (1991). For information about the contribution of Dag Hammarskjöld to the resolution of these crises, see also Remond (1974:267) and Olver (2011:34-69).

3.For more information about this topic and about the end of his life on his return from Congo, see also Tewy-K-Foz (2011:26), Globerman (2011:27) and Redman (2011:28-29).

4.In 1955, after a two-week visit to the Chinese Popular Republic, he was able to release the 15th American pilots imprisoned who had fought under the UN command in Korea. Moreover, he traveled to many countries in Africa, Asia, Europe, America and the Middle East in order to obtain reassurance and to conclude America and the Middle East in order to obtain reassurance and to conclude
agreements with different members of local governments and to solve problems from different areas' (Hanley \& Melber 2011:10). 
who received this distinction after their death (Globerman 1962:769; Mourre 1978:2143; Norberg \& Melber 2012:5; Olver 1962b:131; Renton 2012:21; Sellström 2012).

\section{Aspects of political theology in the spiritual autobiography of Dag Hammarskjöld}

Among the important works of Dag Hammarskjöld, we must mention his spiritual autobiography. Published by his disciples shortly after his death, under the title Markings, ${ }^{5}$ or, according to other editors, Waymarks (Erling 2010), this work, which highlights his struggle with himself (Lyonn 2006-7:80), ${ }^{6}$ makes him the most important author of spiritual autobiographies from the Swedish protestant space of the 20th century (Morariu 2016a:11).

The book contains the personal notes of the second SecretaryGeneral of the United Nations, from 1925 until 1961, just before his death; they are divided into three sections. The first section starts in 1925 and ends in 1930, and is followed by a pause until 1941. A new section follows, containing notes written between 1941 and 1950. The last part presents the notes written during the remaining time until his death (Erling 2010:6-7; Ryan 2016:120).

However, given the content of this work, the reader could ask himself or herself: can we speak about political theology in a spiritual autobiography? Usually, even when we can, it is a rather peripheral topic in a text focused on the inner conflict of the author, his evolution in the spiritual life or his relationship with God (Dinzelbacher 1992:82; Scott 2009:139-140).

The same holds true in the case of Dag Hammarskjöld's notes. Nonetheless, there are some references to politics and diplomacy and to the international context of the time when the article was written. Why? Because some events he took part in determined certain spiritual transformations of the author or influenced his relationship with God and his spiritual life. This is the reason why, especially in the last parts of the spiritual autobiography of Dag Hammarskjöld, we can talk about aspects of political theology. Of course, in the first part and in the first half of the second part, there are also some elements of political theology, ${ }^{7}$ but presented in an almost hidden way, through comparisons or allusions, encoded in short meditations, little pastels or even in haiku poems (Aulen 1969:125; Stolpe 1966:5; Van Dusen 1967:179).

5.Hammarskjöld (1972) (in fact, the first edition of the work was: Dag Hammarskjöld, Markings, translated in English by W.H. Auden and Leif Sjöberg, London, 1963, but we did not have access to it, and Mr. Hening Melber suggested that we use the version edited by Bernhard Erling because of the richness of notes it contained and of its translation).

6. Highlighting these aspects, Thomas Ryan says in one of his articles about Markings: 'Markings, a testimony to Hammarskjöld's cultivated practice of conscious selfscrutiny, is marked by honesty, acute perception and a sense of immediate experience. His writing, with its affective texture, his mastery of rhythm and images, reflects a man of a poetic sensibility' (Ryan 2016:120).

7.Of course, this is an example of situations when the diplomat confessed how events that happened at work influenced his spiritual life: 'He stood erect - like a whip top that happen the lash is swishing. He was modest by virtue of robust feelings as long as the lash is swishing. He was modest by virtue of robust feelings of superiority. He was not demanding: what he strove for was only freedom from anxiety, and the fallures of others delighted him more than his own victories. He saved his life through never risking it. And complained when he was not understood (Erling 2010:7).
There, even if Hammarskjöld does not speak directly about the way in which Churches would influence political life through biblical principles and the attempt to sometimes change the political world (Leuba 1994:203; Schmitt 1985), and even if he does not present specific situations when political theology proved to be functional, we can still find notes about politics, theology and the relationship between them and the way in which they influenced his life.

Conscious of the fact that 'We are not permitted to choose the frame of our destiny. But what we put into it is ours' (Lopez 2012:10), he tried to put in his destiny and in those of other people the Christian values of peace, morality and respect. Peace is his gift for the entire world, in general, and for some African states, in particular. The ideas he expressed are surely useful for the contemporary perception of political theology, not only at a theoretical level, but also from a practical point of view.

Reading his spiritual autobiography, one can definitely notice that, at times, he suffered because of the misunderstanding of his ideas and because of lack of reciprocity to his love. In one of these situations; for example, he characterised some of the people he met during negotiations using a quotation from Thomas of Kempis (Kemfis 1835:249-250), reinterpreted:

The purer the eye of the intention is, the more strength the soul finds within itself ... But it is very rare to find a soul entirely free, whose purity is not at all sullied by some stain of a secret searching for itself... Work, therefore, to purify the eye of your intention in order that it might be single and upright. (Erling 2010:118)

Although it is difficult for one to claim that this passage says something specific about Hammarskjöld's conception of political theology, upon a more careful and thorough reading, the fragment shows that his conception of inner purification can also be relevant for the topic we are interested in. If, sometimes, the attempt to create dialogue fails leading to a real 'clash of civilizations' (Huntington 1993:22), it also happens because most of the time people try to purify the others before purifying themselves. This explains why the results of political dialogues are often weak or not as they were expected to be. Therefore, it would clearly be very useful for people mandated to take part in political life to use this life principle taken from Thomas of Kempis and explained and put into practice by Hammarskjöld; there would be new and interesting results for political theology.

Through such notes, Hammarskjöld also showed that in a world undergoing continuous change (Melber 2012:9), he knew how to translate his religious experience into his diplomatic activity (Barbato 2010:549; Dionigi 2016:162-163). This is perhaps the reason why, in his spiritual autobiography, we cannot find many references to political theology. The reason is that he did not write about it, but he put it directly into practice. 
However, from time to time, in ambiguous texts classified by some of his exegetes as mystical formulas, ${ }^{8}$ yet containing visible allusions to politics, he spoke, for example, about the relationship between work and freedom, developing an interesting approach:

Always: here and now - in that freedom which is one with detachment, in the stillness that is born out of tranquillity. But this freedom is a freedom during activity, this tranquillity is a tranquillity among people. The mystery is a constant reality in the one, who in this world is himself free, a reality in calm maturity during affirmation's receptive attentiveness. The way to sanctification in our time necessarily passes through the world of action. (Erling 2010:146)

This idea of 'tranquillity among people', which is a real exhortation to activism at a social, diplomatic and political level, linked with the belief that 'the way to sanctification in our time necessarily passes through the world of action' (Erling 2010:146), can also be seen under the light of his conceptions of political theology. Doubtlessly, they reveal his militant personality and its roots, which can only be of Christian origin.

In contrast to previous notes, the writings from his last years of life, when crises like the one in Suez, Lebanon or Congo asked for his presence and meditation, contain more notes that mention and discuss peace and other political elements. For example, in 1960, on the occasion of the Easter feast, he wrote:

Easter 1960. Forgiveness breaks the chain of causality through the fact that the one who 'forgives' - in love - takes upon himself the responsibility for the consequences of what you did. It therefore always involves sacrifice. The price of your own liberation through the sacrifice of another is that you yourself must be willing in the same way to liberate, irrespective of the cost. (Erling 2010:254)

His note shows how he saw everything with the eyes of a Christian believer, yet, at the same time, he was not detached from the reality of the surrounding world and he really cared about man's faith. Linking freedom with forgiveness is already quite revealing and does not require any additional comment. In fact, such an approach is common in Dag Hammarskjöld's notes.

Sometimes, he spoke with God about the world's faith; referring to Africa's situation, ${ }^{9}$ his thoughts resulted in beautiful poems like the following:

O You who led us to this naked life of the soul, destiny

Hovering over the waters, will You relate, some earthly evening, Whose the hand is that clothes us with fable's

burning tunic? (Erling 2010:262)

8.This is the explanation of Bernhard Erling of that note: 'In this waymark DH sets forth his understanding of the mystical experience. It is here and now and it takes place in the midst of activity the midst of activity among people. There are many who are convinced that in orde to come close to God one must withdraw from the world to devote oneself entirely to meditation and prayer. DH says that we encounter God in the world of action
(Erling 2010:146).

9.For more information about his contribution to this continental crises, see also Abbink (2015:83-106)
Notwithstanding, despite his literary talent, we must say that the stylistic part is just a peripheral aspect of his notes, which are, as we have tried to demonstrate, full of common senses and linked to reality. His thought, deeply rooted in the Christian faith he practiced, offers to the reader a new direction of action and the fundaments for understanding his or her own vocation and for practicing the Christian principles in the political and diplomatic spaces, among others.

\section{Conclusion}

Even if we cannot label Dag Hammarskjöld's Markings a work of political theology, like we can say, for example, about the book of Peter Leithart about Constantine the Great (Leithart 2010), and even if its main purpose was not to present the way in which the Gospel should be used in the political life from then on, nor to investigate related aspects, we must acknowledge that they do put forward interesting elements of political theology. It is clear that Hammarskjöld was very much concerned with politics in his activity as a Secretary-General of the United Nations and with religion in his personal life. As a consequence, he preferred not to mix them together. However, sometimes, when he speaks about politics and diplomacy, his Christian convictions become obvious. On the other hand, in his notes, there are also texts about the importance of religion in understanding political crises or about the way in which, by using spirituality, he could surpass problems that had a political background. Therefore, through his political ideas, the author offers interesting solutions to problems the humanity of his times faced and highlights his way of thinking and his conception regarding those problems. The novelty of his approach resides in the fact that even his diplomatic actions are 'soaked' with Christian principles to which the writer remains faithful until his death. On the other hand, he speaks about himself or about the others by making reference to specific situations or problems and by showing theologically inspired solutions or principles that can be used by anyone who shares his inner structure or who faces similar dilemmas, which also makes his notes useful for spaces like that of political theology.

The importance of his notes for this topic is amplified by the fact that they are written in a very pleasant way, using a great diversity of styles and having a very clear message both for the secular and the religious world.

\section{Acknowledgements Competing interests}

The author declares that he has no financial or personal relationships which may have inappropriately influenced him in writing this article.

\section{References}

Abbink, J., 2015, 'Religion and politics in Africa: The future of "the secular"', Africa Spectrum 49(3), 83-106.

Aulen, G., 1969, Dag Hammarskjöld's white book: An analysis of markings, Fortress Press, Philadelphia, PA. 
Barbato, M.P., 2010, 'Conceptions of the self for post-secular emancipation: Towards a pilgrim's guide to global justice', Millenium - Journal of International Studies a pilgrim's guide
$39(2), 541-552$.

Bromberger, M. \& Bromberger, S., 1967, Les secrets de l'expedition d'Egypte, 4th edn., Fils Aymon, Paris.

Burchell, S.C. \& Chassigmeux, André, 1967, Le Canal de Suez, Editions RST, Paris.

Dinzelbacher, P. (ed.), 1992, Dictionnaire de la Mystique, Alfred Kroner Verlag, Brepols.

Dionigi, F., 2016, 'Dag Hammarskjöld's religiosity and norms entrepreneurship: A postsecular perspective', Politics and Religion 9(1), 162-163. https://doi.org/ A postsecular perspective', Politi
$10.1017 /$ S1755048315000930

Erling, B., 2010, A reader's guide to Dag Hammarskjöld's waymarks, Dag Hammarskjöld Foundation, St. Peter, MN.

Globerman, N., 1962, Grand Larousse encyclopédique en dix volumes, Tome cinquième, Librairie Larousse, Paris.

Globerman, N., 2011, 'Getting the news', in M.-L. Hanley \& H. Melber (eds.), Dag Hammarskjöld remembered. A collection of personal memories, p. 27, Dag Hammarskjöld Foundation, Uppsala.

Grosser, Alfred, 1965, La politique extérieure de la Ve republique, Editions du Seuil, Paris.

Hammarskjöld, D., 1972, Markings, Faber and Faber, London.

Hammarskjöld, D., 2000, Castle hill, Dag Hammarskjöld Foundation, Uppsala.

Hanley, M.-L. \& Henning, M. (eds.), 2011, Dag Hammarskjöld remembered. A collection of personal memories, Dag Hammarskjöld Foundation, Uppsala.

Huntington, S., 1993, 'The clash of civilizations', Foreign Affairs 72(3), 22-50.

Jacques, A., 1998, Droits de l'hommee d'Evangile. Comment vivre l'universalité des valeurs dans la pluralité des cultures?, Les Editions de l'Atelier, Paris.

Kemfis, T.d., 1835, De l'imitation de Jesus-Christ, transl. A. de Beüil, Abbaye de Beüil, Paris.

Lash, J.P., 1961, Dag Hammarskjöld - Custodian of brush fire peace, Doubleday, New York.

Leithart, P.H., 2010, Defending Constantine: Twilight of an empire and the down of Christendom, InterVarsity Press, Downers Growe, IL.

Leuba, J.-L., 1994, 'Autour de la Theologie politique', in M.P. Grigoris (ed.), Nikos A. Nissiotis, religion, philosophy and sport in dialogue. In memoriam, pp. 203-207, Nissiotis, religion, philosophy and sport
Thessaloniki Seminary Press, Athens.

Lopez, C., 2012, 'Congratulatory message', Development Dialogue 50(50), 9-11.

Lyonn, A., 2006-7, 'Moral motives and policy actions. The case of Dag Hammarskjöld at the United Nations', Public Integrity 9(1), 79-95.

Melber, H., 2012, 'There will always be enough people to fight for a decent future. An Introduction', Development Dialogue 50(60), 9.

Morariu, I.-M., 2015, 'The spiritual autobiography in the Eastern space in the second half of the XIXth and XXth century', Astra Salvensis 3(Suppl 1), 166-174.

Morariu, I.-M., 2016, 'Autobiografia spirituală şi valenţele ei psihologice [Spiritual autobiography and its psychological valences]', Gracious Light 21(1), 27-29.

Morariu, I.-M., 2017a, 'Aspects of applied ethics in the spiritual autobiographies from the orthodox space in the 19th and 20th centuries', in C. Ignatescu, A. Sandu \& T. Ciulei (eds.), Rethinking social action. Core values in practice, pp. 548-557, Lumen Publishing House, laşi.

Morariu, I.-M., 2017b, 'Educational aspects in the spiritual autobiography from the orthodox space of the 19th and 20th centuries', in I. Albulescu, A.-D. Manea, I.-M. Morariu (eds.), Education, religion, family in contemporary society - Proceeding of the conference, pp. 113-123, Lambert Academic Publishing, Saarbrucken.

Morariu, I.-M. \& Josan, Ş., 2016, 'Elements of spiritual autobiography in the literary works of Virgil Gheorghiu', Research and Science Today 9(1), 83-88.

Morariu, M. (Iuliu-Marius), 2016a, Autobiografia spirituală a lui Dag Hammarskjöld o abordare teologică (Spiritual autobiography of Dag Hammarskjöld - a theological approach), Cluj-Napoca, Argonaut Publishing House.

Morariu, M. (Morariu), 2016b, 'Saint Silouane l'Athonite el l'autobiographie spirituelle dans l'Eglise Orthodoxe', Presence d'En Calcat 53(1), 35-39.

Mourre, Michel, 1978, Dictionnaire encyclopedique d'histoire, G-H, Paris, Les Editons Bordas.

Nantet, J., 1986, Histoire du Liban, Les Editions de Tequi, Paris.
Norberg, C. \& Melber, H., 2012, 'Preface', in T. Sellström (ed.), Albert Luthuli and Dag Hammarskjöld-leaders and visionaries symposia in commemoration of the award of the Nobel Peace Prize to Chief Albert Luthuli and Dag Hammarskjöld, p. 5, The Nordic Africa Institute, Dag Hammarskjöd Foundation, The Luthuli Museum, Uppsala.

Olver, J.A., 1962a, Encyclopaedia Britannica, vol. 1, Encyclopaedia Britannica INC, Chicago, IL.

Olver, J.A., 1962b, Encyclopaedia Britannica, vol. 11, Encyclopaedia Britannica INC, Chicago, IL.

Olver, J.A., 1992, Oxford advanced learner's dictionary of current English Encyclopaedic edition, Oxford University Press, New York.

Olver, J.A., 2011, 'Under fire with Dag Hammarskjöld', in M.-L. Hanley \& H. Melber (eds.), Dag Hammarskjöld remembered. A collection of personal memories, pp. 34-69, Dag Hammarskjöld Foundation, Uppsala.

Perse, Saint John. 1993, Correspondence avec Dag Hammarskjöld, Gallimard, Paris.

Redman, C.T.J., 2011, 'A haunting memory', in M.-L. Hanley \& H. Melber (eds.), Dag Hammarskjöld remembered. A collection of personal memories, pp. 28-29, Dag Hammarskjöld Foundation, Uppsala.

Remond, R., 1974, Introduction a l'histoire de notre temps, vol. 3, Le XX siecle - de 1914 a nos jours, Les Editions du Seuil, Paris.

Renton, Nigel A., 2012, 'Dag Hammarskjöld Christian Peacemaker', in The living Church, viewed 30 January 2018, from https://livingchurch.org/2012/01/06/daghammarskjold-christian-peacemaker/

Roger L.W. \& Roger, O., 1991, Suez 1956: The crisis and its consequences, Oxford University Press, Oxford.

Ryan, T., 2016, “'Yes!" And "Thou” in Dag Hammarskjöld's markings: A theological investigation', Irish Theological Quarterly 81(2), 119-137. https://doi.org/ $10.1177 / 0021140015625238$

Sabalbal, H., 2013, L'évolution des fonctions du Secrétaire général de l'ONU, University of Laval, Laval.

Schmitt, C., 1985, Political theology: Four chapters on the concept of Sovereignity, transl. G. Schwab, MIT Press, Cambridge, MA.

Scott, M.M., 2009, 'The evangelical conversion narrative: Spiritual autobiographies in early Modern England', Christianity and Literature 59(1), 139-140. https://doi. early Modern England', Christianity
org/10.1177/014833310905900123

Sellström, T. (ed.), 2012, Albert Luthuli and Dag Hammarskjöld - Leaders and visionaries Symposia in commemoration of the award of the Nobel Peace Prize to Chief Albert Luthuli and Dag Hammarskjöld, The Nordic Africa Institute, Dag Hammarskjöd Foundation, The Luthuli Museum, Uppsala.

Siegfried, A., 1948, Suez, Panama: et les routes maritimes mondiales, avec 33 cartes et graphiques, Nouvelle édition revue et augmentée, Armand Collin, Paris.

Smyth, A., 2010, Autobiography in early modern England, Cambridge University Press, Cambridge, NY.

Smyth, A., 2016, A history of English autobiography, Cambridge University Press, Cambridge, NY.

Stolpe, S., 1966, Dag Hammarskjöld - A spiritual portrait, Scribner's, New York.

Torren, G., 2011, 'Dag Hammarskjold - the Pacemaker', in G. Torren (ed.), Dag Hammarskjold, literature (On the 50th anniversary of his death), pp. 5-7, Dag Hammarskjöld Foundation, Uppsala.

Uruquhart, B., 1972, Hammarskjöld, Knopf, New York.

Uruquhart, B., 2011, Dag Hammarskjöld - A leader in the field of culture, in M.-L. Hanley \& H. Melber (eds.), Dag Hammarskjöld remembered. A collection of personal memories, pp. 16-17, Dag Hammarskjöld Foundation, Uppsala.

Tewy-K-Foz, O., 2011, 'ONU, September 1961', in M.-L. Hanley \& H. Melber (eds.), Dag Hammarskjöld remembered. A collection of personal memories, p. 26, Dag Hammarskjöld Foundation, Uppsala.

Văduva, G. \& Dinu, M.-Ş., 2005, Crizele politico-militare ale începutului de mileniu (political and military crises of the beginning of millenium), Press of the National University for Defense, Bucharest.

Van Dusen, H.P., 1967, Dag Hammarskjöld - The statesman and his faith, Harper \& Row, New York.

Viklund, J., 2008, 'Persuasion in nineteenth-century Swedish fiction: C. J. L Almquist and the "Rhetorical situation"', in P. Harsting \& J. Viklund (eds.), Rhetoric and literature in Finland and Sweden 1600-1900, pp. 1-23, Nordisk Nedvaek for Retorikkens Historie, Copenhagen. 